\title{
THE EFFECTIVENESS OF INDONESIAN NATIONAL POLICE FUNCTION ON BANGGAI REGENCY POLICE INVESTIGATION (Investigation Case Study Year 2008-2016) $^{\Omega}$
}

\author{
Hardianto Djanggih \\ Faculty of Law, Universitas Tompotika Luwuk, Indonesia \\ E-mail: hardianto_djanggih@yahoo.co.id \\ and \\ Kamri Ahmad \\ Faculty of Law, Universitas Muslim Indonesia, Indonesia \\ E-mail: kamriah@yahoo.com
}

\begin{abstract}
Criminal justice processes are frequently unwell-implemented due to various investigators' shortcomings in performing their function. This research aims to determine and analyze the effectiveness of the police investigation in handling of Criminal Offenses in Banggai. This research employed socio-juridical methods approach particularly descriptive analytical research. The data analysis was con-ducted by descriptive qualitative and quantitative analysis. The results showed that: there is an imbalance between investigators and number of crimes; $70 \%$ of suspects were arrested by investigators without warrant; discrimination among suspects in investigation process occurs; investigators would prefer interrogating suspect without being assisted by lawyer; limited information given by the investigators to suspect's family; suspects were detained without according to the applicable law and regulations.
\end{abstract}

Keywords: effectiveness, police, investigation process

\begin{abstract}
Abstrak
Proses peradilan Pidana yang seringkali tidak baik karena disebabkan berbagai kesalahan dan kekurangan-kekurangan penyidik Polri dalam melakukan fungsi penyidikan. Penelitian ini bertujuan untuk mengetahui dan menganalisis efektivitas penyidikan kepolisian dalam proses penanganan Tindak Pidana di Banggai. Penelitian ini menggunakan metode pendekatan metode sosio-yuridis dengan spesifikasi penelitian bersifat deskriptif analitis. Analisis bahan dalam penelitian ini menggunakan diskriptif kualitatif dan analisis kuantitatif. Hasil penelitian menunjukan bahwa: jumlah penyidik tidak seimbang dengan jumlah kejahatan yang terjadi; $70 \%$ penangkapan yang dilakukan penyidik terhadap tersangka tanpa ada surat perintah; adanya diskriminasi antara tersangka dalam proses penyidikan; penyidik lebih suka bila tersangka diperiksa tanpa didampingi pengacara; kurang seriusnya penyidik memberikan informasi kepada keluarga tersangka; penyidik melakukan penahanan terhadap tersangka lebih dari ketentuan hukum yang berlaku.
\end{abstract}

Kata Kunci: efektivitas, polisi, proses penyidikan

\section{Introduction}

1945 Constitution in amendment of Article 1 Paragraph (3), "Indonesia is a law country." The idea or the concept of law country is

$\Omega$ Research of Dosen Pemula Hibah Dikti Year 2014, Research Contract Number: $1625 / K 9 /$ AK.03/2014 on May $16^{\text {th }}$ 2014.

1 Dayanto, "Rekonstruksi Paradigma Pembagunan Negara Hukum Indonesia Berbasis Pancasila", Jurnal Dinamika Hukum, Vol. 13 No. 3, September 2013, Purwokerto: commonly aimed to avoid state or government's arbitrary acts. Anyhow, a government uncontrolled by concrete legal instruments will be vulnerable of deviation and power abuse. Even in the modern era, it is very relevant and ideal

Faculty of Law Universitas Jenderal Soedirman, page 498. 
if any state activities are based on legal mechanism. $^{2}$

Law authorizes police to enforce the law both preventively and repressively in the form of coercive action. Police duties in terms of penal crime policies implements applicative policy which tends to be repressive. ${ }^{3}$ The issue of Law Number 2 Year 2002 on Indonesian National Police, strictly limits the Police duty and authority. The limitation functions as one of the state government duty in terms of maintaining security and public order, law enforcement, protection, defense, and public servants. ${ }^{4}$

One of National Police duties as the law enforcer in criminal justice is investigating the criminal lawsuit in accordance with KUHAP. Before investigating, the police conduct preliminary investigation by selecting the cases whether included in crime or not. If the case is a crime, then a full investigation follows. ${ }^{5}$

Several cases happened lately shows that criminal justice is not well implemented due to investigators' performance. Investigation process is not an easy thing since related to whether a criminal offense conducted by the suspect can be charged by punishment or not.

\section{Problem}

Based on the background, the problem is formulated as how the law enforcement is implemented by police in investigation held in Banggai Regency Police particularly criminal case study investigation from 2008 to 2012 .

2 Janpatar Simamora, "Tafsir Negara Hukum dalam Perspektif Undang-Undang Dasar Negara Republik Indonesia Tahun 1945", Jurnal Dinamika Hukum, Vol. 14 No. 3, September 2014, Purwokerto: Faculty of Law Universitas Jenderal Soedirman, page 548.

3 Agus Rahardjo dan Angkasa, "Profesionalismen Polisi Dalam Penegakan Hukum", Jurnal Dinamika Hukum, Vol. 11 No. 3, September 2011,Purwokerto: Faculty of Law Universitas Jenderal Soedirman, page 395.

4 Mugiman, “Implementasi Undang-Undang Nomor 3 Tahun 1997 Tentang Pengadilan Anak (Studi Terhadap Anak Yang Berhadapan Dengan Hukum Dalam Tingkat Penyidikan Di Polres Purbalingga)", Jurnal Dinamika Hukum, Vol. 10 No. 2, May 2010, Purwokerto: Faculty of Law Universitas Jenderal Soedirman, page 6.

5 Agus Rahardjo, et.al, "Rule Breaking Dalam Penyidikan Untuk Menghindari Kekerasan yang Dilakukan Penyidik", Jurnal Dinamika Hukum, Vol. 13 No. 1, January 2013, Purwokerto: Faculty of Law Universitas Jenderal Soedirman, page 20 .

\section{Research Methods}

This research was conducted in legal area of Banggai Regency Police. The informants were investigators of Banggai Regency Police, advocate, and society. Twenty questionnaires are distributed to respondents. This research used socio-juridical method by descriptive analysis while the data analysis used descriptive qualitative and quantitative analysis. Qualitative descriptive analysis was used to analyze the research result while quantitative data was measured using frequency formula as follows:

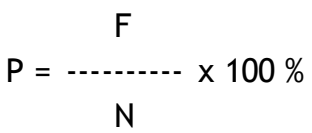

Note:

$P=$ percentage $f=$ frequency $N=$ number of sample

\section{Discussion \\ Investigation Effectiveness in Handling Crim- inal Offenses in Banggai Regency Police}

Systematically, law enforcement and justice is theoretically effective if the 5 law pillars run well, namely legal instrument, law enforcement officers, society, legal culture, facilities to support the law implementation. ${ }^{7}$ Criminal law enforcement is carried out through a system called the Criminal Justice System (CJS). In the CJS, there are supporter institutions including police, prosecutors, courts, and correctional institution. Although the criminal law enforcement has been implemented in a system, the result is still beyond expectations which puts Indonesia as one of the worst countries in law enforcement. $^{8}$

Investigation is a series of investigator acts to seek and to collect evidence in accordance with law that makes the criminal case

6 Soerjono, Soekanto,1983, Faktor-Faktor yang Mempengaruhi Penegakan Hukum, Jakarta: Rajawali, page 284.

7 Sanyoto, "Penegakan Hukum Di Indonesia", Jurnal Dinamika Hukum, Vol. 8 No. 3, September 2008, Purwokerto: Faculty of Law Universitas Jenderal Soedirman, page 199.

8 Agus Rahardjo and Sunaryo, “Pendayagunaan Teknologi Informasi Dalam Pemberdayaan Masyarakat Untuk Mengawasi Bekerjasanya Sistem Peradilan Pidana Di Jawa Tengah", Jurnal Dinamika Hukum, Vol. 10 No. 3, September 2010, Purwokerto: Faculty of Law Universitas Jenderal Soedirman, page 197. 
confirmed and find the suspect. (Article 1 Paragraph (2) Law Number 8 Year 1981). Investigator is the officer of Indonesian National Police or certain civil servants who are given the special authority to conduct the investigation. ${ }^{9}$

Investigation is one of the Police Main Tasks in order to implement law enforcement based on Article 13 letter (b) of Law Number 2 Year 2002 on Indonesian National Police. Meanwhile, related to the Indonesian National Police as an investigator based on Law of Article 14 paragraph (1) letter (g) of Law Number 2 Year 2002 on Indonesian National Police, which stated that the Indonesian National Police has the duty "to conduct preliminary investigation and investigation for all crimes in accordance with criminal procedure law and other laws and regulations." 10

Related to the police investigation in Banggai Regency Police as this research object, Bripka Raini Laato (Banit Idik I, Banggai Regency Police, interviewed at June $27^{\text {th }}, 2014$ ) explained that investigators in doing their duty are always haunted by the Human Rights (HAM) violation. In fact the number of investigators at the Police Criminal Investigation unit Banggai stated by Teddy Polii, SH (Kaur Bin Ops Sat Serse Kriminal Polres Banggai) are 28 officers including 5 senior officers, 23 bitara personnel and 3 personnel of civil servants. Based on that number, said Teddy Polii, SH, it is inadequate comparing to the number of crimes. As a result, some criminal cases remained unhandled. However, the police is committed that the investigators rush to the criminal scene as soon as they are informed.

Related to criminal case, data in Satuan Serse Kriminal Polres Banggai from year 20082016 are explained as follows:

9 Agus Raharjo and Angkasa, “Perlindungan Hukum Terhadap Tersangka Dalam Penyidikan Dari Kekerasan Penyidik Di Kepolisian Resort Banyuman", Jurnal Mimbar Hukum, Vol. 23 No. 1, February 2011, Yogyakarta: Faculty of Law Universitas Gajah Mada, page 83.

10 Dayat Hadijaya, Et.al., "Pelaksanaan Tugas dan Kewenangan Penyidik Polri Dalam Melakukan Tindak Pidana Pengelolaan Lingkungan Hidup", Jurnal Kebijakan dan Pembangunan, Vol. 1 No. 2, 2014, Jakarta: Faculty of Law Universitas Indonesia, page 38.
Table 1. Criminal Case Data of Banggai Regency Police

\begin{tabular}{|c|c|c|c|c|}
\hline \multirow[t]{2}{*}{ No } & \multirow[t]{2}{*}{ Year } & \multicolumn{2}{|c|}{$\begin{array}{c}\text { Number of Criminal } \\
\text { Case }\end{array}$} & \multirow{2}{*}{$\begin{array}{c}\text { Percentage } \\
(\%)\end{array}$} \\
\hline & & Report & Finished & \\
\hline 1 & 2008 & 1438 & 1289 & 89,6 \\
\hline 2 & 2009 & 1437 & 1292 & 89,9 \\
\hline 3 & 2010 & 1788 & 1642 & 91,8 \\
\hline 4 & 2011 & 1544 & 1316 & 85,2 \\
\hline 5 & 2012 & 1708 & 1357 & 79,4 \\
\hline 6 & 2013 & 1823 & 1499 & 82,2 \\
\hline 7 & 2014 & 1015 & 748 & 73,6 \\
\hline 8 & 2015 & 1466 & 1292 & 88,1 \\
\hline 9 & 2016 & 1127 & 716 & 63,5 \\
\hline \multicolumn{2}{|c|}{ Amount } & 13.346 & 11.151 & 83,5 \\
\hline
\end{tabular}

In settlement of criminal cases in Banggai Regency Police based on the data above, it can be understood that there is a decrease in the settlement of crime process. Related to this, Ahmad (resident of district Luwuk interviewed on June $26^{\text {th }}$, 2014) said that the society wished the police perform their function based on legal procedures. In particular, the law enforcement officers (Indonesian National Police Investigators) in Banggai act arbitrarily even to the alleged which is not proven guilty yet. This makes people called them sadistic offficers. Ironically, this practice has been longc carried out since new order till present.

Sukirlan Sandagang (Advocate) (interviewed on June $25^{\text {th }}, 2014$ ) said that he had experience when visiting his client in Police jail but the investigators did not allow him because the client might not be visited. It showed that investigators disobeyed the law. It was against Article 58 KUHAP. Then it is clearly seen that investigators did not want the suspect to be accompanied by the lawyer because it makes them difficult to interrogate the suspect as they wish. In contrast, Bripka Raini Laato (inter-viewed on June $27^{\text {th }}, 2014$ ), said that the pro-cess is procedural based on law (KUHAP).

According to the interview, it is relevant to Erna Dewi's opinion ${ }^{11}$ that Indonesian $\mathrm{Na}$ -

11 Erna Dewi, “Kebijakan Polri Sebagai Penyidik Terhadap Pelaku Tindak Pidana Pencurian Ringan Dalam Mewujudkan Keadilan”, Jurnal Masalah-Masalah Hukum, Jilid 41 
tional Police as law enforcement officers which get the first rank in the criminal justice system in its action cannot be separated from the attitude and behavior as law enforcement officers that always attract society's interest to follow their movement in law enforcement.

The results of interview gained from the police, Advocats and Society, it reveals that the police in conducting the investigation process has tried to execute its duties, but on the other hand, the police find the obstacles that may affect the performance of the investigation process. Thus, Advocats and the society criticize the police performance in investigation process.

In regards to this, questionnaires were distrubuted to the 20 respondents. The purpose of this questionnaire is to examine the responses from the public to the police performance in conducting a series of investigation process at Banggai Police.

The respondents response is in this following table:

Table 2. Respondent's Response on the Arrest by Investigators toward Suspects

\begin{tabular}{c|c|c}
\hline Variable & Frequency & (\%) \\
\hline $\begin{array}{c}\text { With a Letter } \\
\text { of Command }\end{array}$ & 6 & 30,00 \\
\hline $\begin{array}{c}\text { Without a } \\
\text { Letter of } \\
\text { Command }\end{array}$ & 14 & 70,00 \\
\hline Amount & 20 & 100,00 \\
\hline
\end{tabular}

Source: Primary Data 2012

The data can be understood that in conducting an arrest of a person suspected of committing a criminal offense, the investigator is required to show an arrest warrant but $70 \%$ of respondents said there was no warrant for arrest. It means that the investigator has violated the provisions of Article 18 of the Criminal Procedure Code.

An arrest without a warrant is an unlawful arrest unless the perpetrator is red-handed caught. The arrest warrant must clearly contain the identity of the suspect, what kind of crime that is suspected and where he or she is being

No. 2, 2012, Semarang: Faculty of Law Universitas Diponegoro, page 219. examined. It is intended to enable the suspect's to be informed where the suspect is detained.

If a suspect is arrested, the investigator shall not immediately inspect him but the suspect is detained and then processed. Therefore, this is the response of the duration of examination for person that arrested.

Table 3. Respondents' Response to how quick a suspect to be proceeded

\begin{tabular}{l|c|c}
\hline Variable & Frequency & $\begin{array}{c}\text { Percentage } \\
(\%)\end{array}$ \\
\hline $\begin{array}{l}\text { Directly } \\
\text { processed }\end{array}$ & 13 & 65,00 \\
\hline $\begin{array}{l}\text { Indirectly } \\
\text { Processed }\end{array}$ & 7 & 35,00 \\
\hline Amount & 20 & 100,00 \\
\hline
\end{tabular}

The data show there are $35 \%$ of respondents said the arrested suspects are not directly processed. It proves that investigators ignore the valid legal procedures. Article 50 of the Criminal Procedure Code stipulates that if a person is arrested he/she is entitled to be immediately investigated by the investigator.

According to Syahrul, one of the suspects in Banggai Detention, he said that "there is a difference in the suspect, namely immediate examination is conducted for a drug suspect rather than other crimes cases such as theft, murder, fraud, embezzlement and so on. The Banggai Police investigator has abused his authority as given by KUHAP that there is discrimination between drug suspect and other crime suspects". He claimed that they came in at the same time but the Drugs suspects who got the examination first, and later next two days already got a turn to be examined.

Almost all suspects in detention of investigators are perpetrators of crimes that are sentenced to 5 (five) years and it means they can be accompanied by the lawyer.

Table 4. Respondent's Response toward the Right to be Accompanied by a Lawyer during investigation

\begin{tabular}{l|c|c}
\hline \multicolumn{1}{c|}{ Variable } & Frequency & $(\%)$ \\
\hline $\begin{array}{l}\text { Accompanied by } \\
\text { lawyer }\end{array}$ & 1 & 5,00 \\
\hline $\begin{array}{l}\text { Not accompanied by } \\
\text { lawyer }\end{array}$ & 19 & 95,00 \\
\hline \multicolumn{1}{c}{ Amount } & 20 & 100,00 \\
\hline
\end{tabular}

Source: Primary Data 2012 
The table above shows that $95.00 \%$ of the suspects are not accompanied by the lawyer during investigation. Whereas, Article 52 of the Criminal Procedure Code stated that any crimes sentenced to five years and above are entitled to be accompanied by Lawyer at all of inspection levels. In fact, they are not. It is undeniable that unaccompanied suspects are vulnerable for mistreatment by the investigators.

Under the provisions of legislation that a person is caught at the crime scene and held in detention then shortly after the arrest is obliged to inform to his family in order to grant a suspension of detention.

Table 5. The Response on Police Notification to the Suspect Family

\begin{tabular}{l|c|c}
\hline Variable & Frequency & (\%) \\
\hline $\begin{array}{l}\text { Immediately } \\
\text { Delivered }\end{array}$ & 15 & 75,00 \\
\hline $\begin{array}{l}\text { Not Immediately } \\
\text { Delivered }\end{array}$ & 5 & 25,00 \\
\hline $\begin{array}{l}\text { Amount } \\
\text { Source: Primary Data 2012 }\end{array}$ & 20 & 100,00 \\
\hline
\end{tabular}

The data show the investigator in carrying out their duties in delivering news to the family of the suspect. The investigator shall understand that all suspects in the detention shall be equally treated including news to the families of the suspects relating to his arrest as it is the right of each suspect, as defined in Articles 59 and 60 of the Criminal Procedure Code. However, the reality in the field has not been implemented optimally. In addition to these rights, the suspect has also a right to be visited by his relatives. This right is affirmed in Article 61 of the Criminal Procedure Code and this right is fulfilled that the investigator still gives the opportunity for the family to visit the suspect in detention.

Detention of a suspect in the police investigation process can only be granted within a 20 days and this detention may be extended by the competent public prosecutor for a maximum period of forty days. If for sixty days the investigation has not been completed, the suspect must be released from detention by law.
Table 6. Respondents' Response on the Duration of Suspects Detained by Investigators

\begin{tabular}{l|c}
\hline The duration of detention & The number \\
\hline 20 until 60 days & 19 \\
\hline More than 60 days & 1 \\
\hline Amount & 20 \\
\hline Source: Primary Data 2012
\end{tabular}

Source: Primary Data 2012

The data above indicate that the investigator has committed a law violation for having detained one person more than the law provision. As stated on Article 39 of the Criminal Procedure Code that a person who has been detained for 60 days and the investigator has not been able to solve the investigation, then in the name of law, the suspect should be released.

In carrying out its duties, each police shall refer to the provision and law to perform their duties but in fact the laws and regulations have not been able to give a positive attitude of the police in carrying out the task. Positive attitude is the member's mental attitude of the Indonesian National Police in carrying out the duties as law enforcers that there are still many violations either law violation, discipline violation, or code of ethics. ${ }^{12}$

\section{Conclusion}

Based on the description, the investigation processes in Banggai from 2008 to 2016 conducted by the police has not been effective for several reasons. First, the number of investigators is not adequate comparing to the number of crimes, yet, the police still seek to immediately solve every case accordance with the provisions in valid legislation; second, $70 \%$ of arrests were made by the Investigator without any warrant. An arrest without a warrant is an unlawful arrest unless the perpetrator is caught by the investigator at the crime scene. The warrant enables the suspect family to be informed where the suspect is detained; third, There is discrimination between suspects in the investigation process. This is contrary to the

12 Sayed Muhammad Rafsanjani, et all, “Terhadap Pemeriksaan Tersangka Yang Dilakukan Penyidik Kaitannya Dengan Kode Etik Kepolisian Negara Relublik Indonesia”, Jurnal Ilmiah Hukum, Vol. 3 No. 3, 2015, Banda Aceh: Postgraduate Program of Syiah Kuala University, page 65. 
principle of equality before the law; fourth, the Investigator prefers the suspect to be examined without a lawyer. This is not in line with the criminal justice process, because the advocate function is to accompany the litigants in the legal process undertaken; fifth, lack of serious investigators related to provide information for the suspect family. The investigator should have underlined Article 59 and 60 of the Criminal Procedure Code since it is part of the rights of the suspect; sixth, the Investigator arrests suspect more than the amount set in provisions of valid law. As in Article 39 of the Criminal Procedure Code that a person who has been detained for 60 days and then the investigator can not fix the investigation, so in the name of law, he or she is must be released.

\section{Suggestion}

Based on the results of the study, the authors provide the following suggestions: first, the police as investigators on handling cases of criminal acts is expected to carry out their duties according to the Criminal Procedure Code (Law Number 8 Year 1981), The Police Act (Law Number 2 Year 2002) and other legislation; secondly, for the parties who involved in criminal cases should be proactive, such always questioning the investigator's progress towards criminal proceedings.

\section{Reference}

Dayanto. "Rekonstruksi Paradigma Pembagunan Negara Hukum Indonesia Berbasis Pancasila". Jurnal Dinamika Hukum. Vol. 13 No. 3. September 2013. Purwokerto: Faculty of Law Universitas Jenderal Soedirman;

Dewi, Erna. "Kebijakan Polri Sebagai Penyidik Terhadap Pelaku Tindak Pidana Pencurian Ringan Dalam Mewujudkan Keadilan". Jurnal Masalah-Masalah Hukum. Jilid 41. No. 2. 2012. Semarang: Faculty of LawUniversitas Diponegoro;

Hadijaya, Dayat. Et al. "Pelaksanaan Tugas dan Kewenangan Penyidik Polri Dalam Melakukan Tindak Pidana Pengelolaan Lingkungan Hidup". Jurnal Kebijakan dan Pembangunan. Vol. 1 No. 2. 2014. Jakarta: Faculty of Law Universitas Indonesia;
Mugiman. “Implementasi Undang-Undang Nomor 3 Tahun 1997 Tentang Pengadilan Anak (Studi Terhadap Anak Yang Berhadapan Dengan Hukum Dalam Tingkat Penyidikan Di Polres Purbalingga)". Jurnal Dinamika Hukum. Vol. 10 No. 2. Mei 2010. Purwokerto: Faculty of Law of Jenderal Universitas Soedirman;

Rafsanjani, Sayed Muhammad. Et.al. “Terhadap Pemeriksaan Tersangka Yang Dilakukan Penyidik Kaitannya Dengan Kode Etik Kepolisian Negara Relublik Indonesia". Jurnal Ilmiah Hukum. Vol. 3 No. 3. 2015. Banda Aceh: Postgraduate Program of Syiah Kuala University;

Rahardjo, Agus dan Angkasa. "Perlindungan Hukum Terhadap Tersangka Dalam Penyidikan Dari Kekerasan Penyidik Di Kepolisian Resort Banyuman". Jurnal Mimbar Hukum. Vol. 23 No. 1. February 2011. Yogyakarta: Faculty of Law Universitas Gadjah;

Rahardjo, Agus dan Angkasa. "Profesionalismen Polisi Dalam Penegakan Hukum". Jurnal Dinamika Hukum. Vol. 11 No. 3. September 2011. Purwokerto: Faculty of Law of Universitas Jenderal Soedirman;

Rahardjo, Agus dan Sunaryo. "Pendayagunaan Teknologi Informasi Dalam Pemberdayaan Masyarakat Untuk Mengawasi Bekerjanya Sistem Peradilan Pidana Di Jawa Tengah". Jurnal Dinamika Hukum. Vol. 10 No. 3. September 2010. Purwokerto: Faculty of Law Universitas Jenderal Soedirman;

Rahardjo, Agus. Et.al. "Rule Breaking Dalam Penyidikan Untuk Menghindari Kekerasan yang Dilakukan Penyidik". Jurnal Dinamika Hukum. Vol. 13 No. 1. January 2013. Purwokerto: Faculty of Law Universitas Jenderal Soedirman;

Sanyoto. "Penegakan Hukum DI Indonesia”. Jurnal Dinamika Hukum. Vol. 8 No. 3. September 2008. Purwokerto: Faculty of Law Universitas Jenderal Soedirman;

Simamora, Janpatar. "Tafsir Negara Hukum dalam Perspektif Undang-Undang Dasar Negara Republik Indonesia Tahun 1945". Jurnal Dinamika Hukum. Vol. 14 No. 3. September 2014. Purwokerto: Faculty of Law of Universitas Jenderal Soedirman;

Soekanto, Soerjono. 1983. Faktor-Faktor yang Mempengaruhi Penegakan Hukum. Jakarta: Rajawali. 